\title{
OVERVIEW OF RUSSIAN CIVIL JUSTICE
}

\author{
DMITRY MALESHIN, \\ National Research University Higher School of Economics \\ (Moscow, Russia)
}

DOI: $10.21684 / 2412-2343-2016-3-4-41-70$

Contemporary Russian civil procedure is not a pure Continental model because it also has procedural features of the common law system, as well as some other original and exceptional features. This article examines the main aspects of Russian civil justice: its main principles; judicial organization, including the structure of the courts and the division between courts of general jurisdiction and arbitrazh (commercial) courts, and the Intellectual Property Court; sources of procedural law; bar organization; the jurisdiction of the courts; actions and proceedings; legal costs; evidence; administrative procedure; class actions; enforcement proceedings; and arbitration and mediation.

Keywords: Russian civil justice; class actions; enforcement proceedings; administrative justice; arbitration; mediation.

Recommended citation: Dmitry Maleshin, Overview of Russian Civil Justice, 3(4) BRICS Law Journal 41-70 (2016).

\section{Table of Contents}

\section{Introduction}

1. Distinction between the Types of Procedure

2. Brief Historical Perspective

3. Judicial Organization

3.1. General Information

3.2. Structure of the Court System

3.3. Supreme Court of the Russian Federation

\subsection{Intellectual Property Court}




\subsection{Juries}

\subsection{Judicial Statistics}

\section{Stages}

\subsection{The Institution of a Civil Case}

4.2. Preparation for the Trial

\subsection{Trials}

4.4. Review Proceedings

5. Administrative Procedure

6. Class Actions

\section{Enforcement of Judgments}

8. Arbitration

\section{Conclusion}

\section{Introduction}

Similar civil procedural outlines exist today in Continental and Anglo-Saxon legal systems. Before addressing which attributes exist in Russia, it is necessary to note that contemporary Russian civil procedure is a mixed jurisdiction. Historically, it adhered to the civil law tradition. ${ }^{1}$ The French Code of Civil Procedure influenced Russian pre-revolution (1917) civil procedural legislation. ${ }^{2}$ During the Soviet era judges became much more active and this model was fairly labeled "the radical Communist solution" to the Continental civil procedure. ${ }^{3}$ In Russia, the court could not act passively because of the widespread collective views in society. ${ }^{4}$

According to the Soviet patriarch of jurisprudence Andrei Vyshinsky, law is entirely and completely directed against exploitation and exploiters in the Soviet state; it is used as one of the means of the struggle for socialism. ${ }^{5}$

There are Continental features in Russian law such as case management, the absence of a jury in civil cases and the absence of class actions. Some common law features also exist in Russian civil procedure, for example the passive role of the judge in the process of proof-taking. Exceptional features of Russian civil procedure

John H. Merryman, The Civil Law Tradition: An Introduction to the Legal Systems of Western Europe and Latin America 121 (1969).

2 Don W. Chenworth, Soviet Civil Procedure: History and Analysis, 67 Transactions of the American Philosophical Society 3 (1977).

3 Mauro Cappelletti, Social and Political Aspects of Civil Procedure: Reforms and Trends in Western and Eastern Europe, 69 Michigan Law Review 847 (1971).

4 Harold J. Berman, Justice in the USSR: An Interpretation of Soviet Law 216-220 (New York: Vintage Books, 1963).

5 Andrei Vyshinsky, The Law of the Soviet State 50 (New York: Macmillan, 1948). 
are the role of the procurator in the civil process and the review of judgments in the "supervisory" instance.

In summary then, contemporary Russian civil procedure is not a pure Continental model because it contains features of the common law procedural system as well as some other original and exceptional features. ${ }^{6}$

The 1990s in Russia were marked by major political and economic reforms. Those significant transformations inevitably changed relations within society, and the legal regulations that were supposed to control them demanded a considerable change as well.

A grandiose legal reform which affected all branches of law was carried out. The transformations in the sphere of civil procedure which began in the early 1990s are still ongoing today and have included the introduction of new legislation, from the Civil Procedural Code of the Russian Federation to enforcement laws.

\section{Distinction between the Types of Procedure}

There are three different types of procedure: civil, arbitrazh (commercial) and administrative. Each type of procedure is regulated by a separate code. In addition to the Civil Procedural Code (2003), there are the Arbitrazh (Commercial) Procedural Code (2002) and the Code of Administrative Procedure (2015).

The Civil Procedural Code regulates procedure relating to the disputes arising from civil, housing, family, labor and other legal relationships. Arbitrazh (commercial) procedure relates to justice in the sphere of entrepreneurial (business) and other economic activities, and the settlement of economic disputes. Administrative procedure relates to the consideration of cases arising from public legal relations. For example, consideration of applications challenging legal regulations, cases relating to electoral rights protection or cases relating to the protection of the right to participate in a referendum by citizens of the Russian Federation.

Consideration also relates to cases in which the issue is to establish certain legal facts, the legal status of a person, the presence or absence of the indubitable rights which could be proved by a court decision. The ex parte proceeding also names the mandative proceedings as a proceedings arising from indubitable claims. For example, claims based on notarized transactions are considered mandative proceedings.

\section{Brief Historical Perspective}

Current Russian civil procedural law is the result of mixing the Soviet style of adjudication with the pre-revolutionary laws of the nineteenth century, as well as with modern international standards. Some features are unique, with their roots in

\footnotetext{
6 Dmitry Maleshin, The Russian Style of Civil Procedure, 21 Emory International Law Review 545 (2007).
} 
ancient Russian laws and traditions. Moreover, the specificity of the legal culture should also be taken into account.

Historically, Russian civil procedure has been close to the European continental system. Different parts of the Russian system were adopted in different historical periods: Byzantine law $\left(9^{\text {th }}-10^{\text {th }}\right.$ century); Swedish law $\left(18^{\text {th }}\right.$ century); French law $\left(18^{\text {th }}-19^{\text {th }}\right.$ century $)$; and German law $\left(19^{\text {th }}-20^{\text {th }}\right.$ century).

The first written legal act was the trade agreement entered into between Prince Oleg and the Byzantine Empire in 911. Byzantium had a significant economic, trade and cultural influence on the Kievan Rus during that time. Slavs adopted many Byzantine legal institutions, especially criminal procedure and evidence.

Codified acts play the key role in the subsequent history of Russian civil procedure. Some of them are completely devoted to civil legal proceedings, some contain only a special section on this matter. Those documents are:

- Russkaia Pravda, $11^{\text {th }}$ century;

- The Pskov Judicial Charter (Pskovskaia Sudnaia Gramota), 1397;

- The Novgorod Judicial Charter (Novgorodskaia Sudnaia Gramota), 1471;

- The Law Code (Sudebnik), 1497;

- The Law Code (Sudebnik), 1550;

- The Sobornoe Ulozhenie, 1649;

- The Civil Procedure Code of the Russian Empire (Ustav Grazhdanskogo sudoproisvodstva), 1864;

- The Civil Procedure Code of the RSFSR (Russian Soviet Federative Socialist Republic), 1923;

- The Civil Procedure Code of the RSFSR (Russian Soviet Federative Socialist Republic), 1964;

- The Civil Procedural Code of the Russian Federation, 2003.

Russkaia Pravda contains a number of rules on civil evidence and litigation. The power to consider cases belonged only to the Prince. Some rules on evidence were original, some were adopted from Byzantine law.

With the adoption of Christianity, canon law (also from Byzantium) began to play a very important role. It regulated marriage, divorce and all family conflicts.

Two key acts entered into force in the fourteenth-fifteenth century: the Pskov Judicial Charter (Pskovskaia Sudnaia Gramota) of 1397 and the Novgorod Judicial Charter (Novgorodskaia Sudnaia Gramota) of 1471. They were enacted despite the dominion of the Tatar-Mongol Yoke; most legal procedures originated from the Russkaia Pravda, and Mongol litigation practices were not adopted.

The Judicial Code (Sudebnik) of 1497 and the Judicial Code (Sudebnik) of 1550 started to regulate the judicial procedure in a more detailed manner than previously. The main judicial power belonged, as before, to the Prince. There were also regional governors who had the right to consider some cases, but their decisions could be appealed to the Prince. There were also different judicial officials who assisted in the 
consideration of cases. The main evidence used in civil cases was witness testimony. Judicial duels were also widespread. Proceedings during that time were adversarial.

The Sobornoe Ulozhenie of 1649 is the most important legal act of medieval Russia. It is an example of the first structural codification of civil procedural law in Russia. It was influenced not only by previous norms based on Byzantine law, but also by the legislation of the Lithuanian Code of 1588. That same Code, moreover, directly applied in a number of north- and south-western Muscovite territories. ${ }^{7}$ The proceedings remained adversarial in nature.

The next important step was the modernization of the Russian legal system by Peter the Great. Modernization during that period is usually described as Westernization. Sweden served as an example for many changes, including legal changes. Civil procedure was also updated in accordance with Swedish legislation. This ended the adversarial model and introduced an inquisitorial model.

The Great Judicial Reform of 1864 was a major legal event in the pre-revolutionary period. It was initiated by Tsar Alexander II and is treated as a part of his Great Reforms in accordance with his political and economic reforms agenda. It abolished previous legislation and established a new model. Civil procedure became oral and adversarial. Justices of the peace and professional attorneys were introduced. Courts and judges acquired genuine independence. Practices of litigation changed radically.

The Reform concerned the judicial system; but civil and criminal procedure, as well as civil and criminal laws, were also reformed within a few years of its launch. It was a very important reform for Russian society. Most legal institutions were not only updated, but re-established. A new legal landscape was created for the huge country.

The Reform touched the territory not only of contemporary Russia, but also of the modern countries of Poland, Finland, Ukraine and Belorussia, and the states of the Caucasus and the Baltic regions. Its legal background has not only Russian national juridical roots, but also French, German, Austrian and Italian influence. Therefore, the Reform has not only national (Russian) dimensions, but also a common trans-European sense. It should be seen as a common European and Eurasian legal event, one that influenced the legislation and legal culture of many countries in the region during a substantial time period. For example, the Russian Civil Procedure Code was in effect until 1933 in Poland ${ }^{8}$ and until 1940 in Lithuania' (sixteen and twenty-three years after the collapse of the Russian Empire). Most of its parts were copied, with only the names changed, by the Soviet authorities during the drafting of the USSR codes.

7 Maxime Kovalevsky, Modern Customs and Ancient Laws of Russia 51 (London: David Nutt, 1891).

8 Piotr Rylski \& Karol Weitz, The Impact of the Russian Civil Judicial Proceedings Act of 1864 on Polish Civil Proceedings, 2(4) Russian Law Journal 82 (2014).

9 Dalia Mikulènienè \& Valentinas Mikelènas, Reception of Russian Statute of Civil Procedure of 1864 in Lithuania during 1918-1940, 2(4) Russian Law Journal 105 (2014). 
The Great Judicial Reform is treated as one of the most successful innovations of Tsar Alexander II. It was undertaken owing to the influence of the West on Russia. ${ }^{10}$ It began in November 1864, but it was preceded by more than ten years of intricate drafting work. The drafting committee was established at the beginning of the 1850s and included a number of well-known Russian lawyers. The first result of this work was the prepared conception of innovations that was adopted by the Tsar on 29 September 1862. The document was titled "General Provisions of Judicial Reforms," and after publication it received huge public discussion: 446 proposals were submitted to the drafting committee from judges, prosecutors and attorneys. Final drafts were signed by the Tsar on 20 November 1864. Four statutes were adopted: Statute of Judicial Institutions; Criminal Procedure Code; Civil Procedure Code; Statute on Punishments. A few years following implementation of the reform all of the drafting papers were collected into seventy-four volumes.

The drafts were greatly influenced by the ideas of the Russian jurist Michael Speransky (1772-1839) who tried to reform Russian law in 1820s, as well as by the new European codes of the second half of the nineteenth century. The main idea of the Reform was expressed by Alexander II in his statement that he wished "to introduce into Russia legal proceedings that are swift, just, merciful and equal for all" (Decree of 20 November 1864).

The new Russian judicial system of that time was based on the following principles: an independent judiciary, oral and adversarial trial, equality of all before the law, introduction of legal representation, an educated legal profession, an independent bar association, jury trial for serious criminal cases and justices of the peace.

Judicial Reform marked a shift in Russian from an amorphous, corrupt system of procedure to an independent, modern system as liberal as any nation in Europe." However, two aspects of the Reform can be viewed in a negative light. First, the Reform was realized in the main towns of the country and did not extend the court system into the villages, where traditional peasant justice continued to operate with minimal influence from the government. The new court system was effective, but it was realized only with respect to 20 percent of the population, because 80 percent were peasants.

Second, the codes did not have effective practice. They were among the best European codes, but were unsuccessful in Russia. One may reasonably agree with many Russian and foreign scholars who argue that norms which are successful for Europe do not necessary work properly in Russia. ${ }^{12}$ The Civil Procedure Code is

10 Vladimir Przhilenskiy \& Maria Zakharova, Which Way is the Russian Double-Headed Eagle Looking?, 4(2) Russian Law Journal 12 (2016).

11 Brian Conlon, Dostoevskyv. the Judicial Reforms of 1864: How and Why One of Nineteenth-Century Russia's Greatest Writers Criticized the Nation's Most Successful Reform, 2(4) Russian Law Journal 8 (2014).

12 Berman 1963, at 216. 
a good example. Twenty years after its adoption, a special drafting committee was established to prepare a new code.

In spite of these negatives, the Reform made the Russian judicial system open, adversarial and more professional. It could be treated as the starting point of a new period in the history of the Russian judiciary that continues to the present day. Contemporary Russian civil and criminal procedure, notary, justices of the peace, juries, etc.: all of the major aspects of these institutions have their roots in 1864.

Soviet civil procedure (1917-1991) was radically inquisitorial. Soviet judges were more active than their European civil law counterparts. Proceedings were overseen in accordance with the principle of "objective" (material) truth. Objective truth is usually used in civil procedure doctrine in contrast to formal truth. Material truth was an important part of Soviet legality. This principle was crucial in evidence gathering. The main task was to find objective truth. A judge was obliged to ascertain the truth and, therefore, had the power to obtain any evidence that he needed to consider the case.

In addition to the judge's activity, there were some other particular features of Soviet civil procedure. Firstly, procurators had immense powers. The Procurator General could initiate the inspection of any case considered by a court. Secondly, there was an additional appeals stage called "supervisory proceedings." Supervisory proceedings were similar to cassation but could be initiated by certain official authorities as well as the parties.

The new Constitution of the Russian Federation was approved in 1993. It was adopted by national referendum on 12 December 1993 with 54.5 percent of the vote, and it took effect on the day it was published -25 December of the same year. The new Constitution set out the fundamentals of government as well as proclaiming the rule of law, the ideological neutrality of the state, political pluralism, competitive elections and separation of powers, and guaranteeing fundamental human rights to the Russian people. It also proclaimed a number of important principles of civil procedure such as the independence of judges, adversarial proceedings and orality.

The new Civil Procedural Code was adopted in 2003 after ten years of official drafting. There is also the Arbitrazh (Commercial) Procedural Code (2002) and the Code of Administrative Procedure (2015).

International accords are also a source of civil procedural law. Russia is a party to nearly forty multilateral and bilateral international treaties, conventions and agreements on legal aid rendering in civil and commercial cases, binding the Russian Federation and more than one hundred signatory states with international obligations.

Some of the most considerable multilateral international treaties containing legal procedural norms are the following:

- Hague Convention of 1 March 1954, on Civil Procedure;

- Hague Convention of 15 November 1965, on Service Abroad of Judicial and ExtraJudicial Documents in Civil and Commercial Matters; 
- Hague Convention of 18 March 1970, on the Taking of Evidence Abroad in Civil or Commercial Matters.

The Soviet Union joined the Convention of 1954 in 1967, and the Russian Federation joined the Conventions of 1965 and 1970 in 2001. Forty-one states currently participate in the Hague Conventions. A considerable number of bilateral international treaties were signed by the Soviet Union, and Russia is a party to those as the successor state.

\section{Judicial Organization}

\subsection{General Information}

The Russian judiciary is regulated by special chapter 7 "Judiciary" of the Constitution as well as by the special laws "On the Judicial System" (1996), "On Courts of General Jurisdiction" (2011), "On Commercial Courts" (1995) and "On the Status of Judges in the Russian Federation" (1992).

All judges of the federal courts are appointed to their position according to Article 128 of the Constitution. Depending on the level of the courts, some judges are appointed by the Federation Council of the Federal Assembly of the Russian Federation and others by the President of the Russian Federation. In order to become a judge a person must be a citizen of Russia, be at least twenty-five years old, have a university degree in law and have at least five years of legal service. Before presenting the applicant for the judge's position, there is a preliminary coordination of the candidacy with the qualifications commission of judges. The Highest Qualifications Panel of judges is a non-governmental organization of the Russian judiciary that plays a key role in the appointment, promotion and dismissal of judges.

The Chairman of the Supreme Court of the Russian Federation is nominated by the President of Russia and appointed by the Federal Council of the Federal Assembly of the Russian Federation for a six-year term. The deputy chairmen of the Supreme Court and other judges of the Court are appointed similarly, but the President's nomination is based on the nomination by the Chairman of the Supreme Court.

All other federal judges - from chairmen of the regional courts to judges of district courts - are appointed to their positions by the President upon nomination by the Chairman of the Supreme Court in coordination with the qualifications commission of judges and with the opinion of the regional parliaments.

According to the Constitution (Art. 118), justice in Russia is administered by the courts alone. The independence of judges is considered a separate constitutional principle (Art. 122) as it concerns the personal security of the judge, members of his family, his dwelling and property, and also his office. The judge is granted the right for the storage and carrying of firearms. The financing of the courts comes from the federal budget and must provide for the possibility of the full and independent implementation of justice. Additionally, there is a special law "About Additional 
Guarantees of Social Protection of Judges and Workers of Courts' Offices of the Russian Federation" (1996).

\subsection{Structure of the Court System}

Today the Russian civil judiciary is composed of the courts of general jurisdiction, military courts, commercial courts and the Intellectual Property Court. The main law governing the fundamental principles of the Russian court system is the Law "On the Judicial System of the Russian Federation" (1996).

Arbitrazh (commercial) courts are charged with settling economic disputes, while courts of general jurisdiction handle disputes between individual citizens. The arbitrazh court system was established in 1991 after the collapse of the Soviet Union and the adoption of a market economy. Arbitrazh courts are structured as a three-tier system. The main law governing the activity of arbitrazh courts is the Law "On Arbitrazh Courts in the Russian Federation" (1995). Arbitrazh courts also have exclusive jurisdiction over the recognition and enforcement of foreign court decisions and arbitral awards. There are four levels in the system of arbitrazh courts: 85 regional courts, 21 appellate courts, 10 territorial courts and the Supreme Court.

The competence of the courts of general jurisdiction includes civil disputes, appeals of administrative actions, labor and employment disputes, family law and consumer protection, among other types of cases. There is a general rule that all cases not referred to the arbitrazh courts are handled by the courts of general jurisdiction. The main law governing the activity of the courts of general jurisdiction is the Law "On the Courts of General Jurisdiction of the Russian Federation." There are three levels in the system of the courts of general jurisdiction: district courts, regional courts and the Supreme Court. District courts are established based on the administrative divisions of a region and regional courts operate on the level of the region (i.e. a subject of the Federation). There are eighty-five regions in Russia.

Justices of the peace handle property disputes with an amount of claim under 50,000 RUR and some types of family cases.

Military courts deal with civil cases that fall under the jurisdiction of the courts of general jurisdiction that occur while service in the military services is involved.

Owing to its adherence to international treaties, Russia is subject to the jurisdiction of the European Court of Human Rights and the Court of the Eurasian Economic Community.

\subsection{Supreme Court of the Russian Federation}

The Supreme Court is the highest court for all courts in Russia. It was established in 1923 as the Supreme Court of the USSR and in 1992 it began to function as the highest court of the Russian Federation.

Depending on the case, the Supreme Court may handle appeal, cassation and supervisory cases, as well as act as a court of first instance. One of the tasks of the 
Supreme Court is the harmonization of judicial practice. In carrying out this task it reviews and analyzes court practice, and as a result of this activity it may issue clarifications and interpretations of the law.

The most important and widely reported legal event in Russia of the last five years was the reform of the Supreme Court, which in fact saw the unification of the Supreme Court and the Supreme Arbitrazh (Commercial) Court.

Until 2013 there had been two parallel supreme courts in Russia: the Supreme Court and the Supreme Arbitrazh (Commercial) Court. This changed in 2014 when the two courts were united. This reform was undertaken at the initiative of President Vladimir Putin under the bill titled "About the Supreme Court of the Russian Federation and Prosecutor's Office of the Russian Federation," which regulates the structure of the Russian judicial system, and which changed the Constitution for the second time since its adoption. The Supreme Arbitrazh (Commercial) Court was abolished and its functions transferred to the Supreme Court. This reform idea proved highly controversial. With advantages and disadvantages, it was hotly debated among lawyers and members of the judicial community, attracting criticism from some. More than 100 law offices signed a petition to stop the reform's progress, arguing that the work of the Supreme Arbitrazh (Commercial) Court had been most effective. On the other hand, authors of the reform asserted the need to eliminate differences and contradictions in the judicial practice of both supreme courts.

The new united Supreme Court of the Russian Federation began its work in August 2014. It has a new structure and consists of 170 judges, including the Chief Justice, and chairmen of six chambers, which are: an Appeals chamber, a Judicial chamber for criminal cases, a Judicial chamber for civil cases, a Judicial chamber for economic cases, a Judicial chamber for administrative cases, and a Military chamber. The Supreme Arbitrazh Court had its functions suspended in August 2014, but the entire arbitrazh court system is still working. The Judicial chamber on economic cases acts as the final instance for economic cases considered in arbitrazh (commercial) courts.

The Plenum of the Supreme Court consists of all judges of the Supreme Court. The Plenum deals with the most complicated matters regarding the functioning of the general jurisdiction courts and the administration of justice. The Plenum reviews and clarifies information on the application of legal practice and decides matters on the introduction of legal initiatives as well as on requests to the Constitutional Court of the Russian Federation regarding constitutional law and the verification of other legal acts. The Plenum also approves the composition of the judicial chambers, the panels and the secretary of the Plenum, and the Scientific and Consulting Council under the Supreme Court of the Russian Federation. The Prosecutor General and the Minister of Justice can participate in the Plenum sessions. They or their substitutes have the right to make correspondent introductions to be heard during the Plenum sessions. They also have the right to express their opinions on the matters in discussion. Plenum sessions should be organized to take place at least once every four months. 
The Presidium of the Supreme Court is the highest and the final judicial instance for cases viewed under general jurisdiction. The Presidium consists of the Chief Justice and his deputies. Among the members of the Presidium of the Supreme Court are some of the most respected judges of the Supreme Court. The total number of Presidium members is thirteen. The composition of the Presidium is approved upon introduction by the President of the Russian Federation, based on the presentation of the Chief Justice and a positive resolution by the Highest Qualification Panel of judges. The Presidium of the Supreme Court hears cases when the majority of its members are present. The Supreme Court has original jurisdiction in certain cases. Those cases include: challenges to individual acts of the Federal Assembly and decrees by the President of Russia and the government of Russia; challenges to delegated legislation of governmental agencies; termination of political parties and all-Russian NGOs; challenges to actions of the Central Electoral Commission of Russia when organizing presidential elections, State Duma (Russia's parliament) elections or referendums. The Supreme Court may also hear criminal cases against members of the Federation Council of Russia and the State Duma, and federal judges, at its discretion. Presidium sessions should be organized to take place at least once each month.

The Academic Consultative Council is a body created to assist the Supreme Court in various legal and academic matters. It comprises members of the Supreme Court itself, academics, practicing lawyers and law enforcement officers. Its composition is approved by the Plenum; it is presided over by the Chief Justice. The Scientific and Consulting Council elaborates scientifically based recommendations on the most complex and important issues of judicial practice. These recommendations may be elaborated as preparation for the clarifications by the Plenum on issues of judicial practice, law projects and preparation of other legal acts, and in respect of specific case trials.

There is also a large number of clerks working in agencies and departments who deal with matters such as the analysis of judicial practice, legislation, personnel and state services, administration, planning and finance, economics, legal information and international law.

\subsection{Intellectual Property Court}

The Intellectual Property Court (IP Court) is a specialized Russian court. It acts as a part of the commercial courts system. The scope of its competence covers disputes connected to intellectual rights.

This category of disputes is notable not only for the complexity of the legal analysis but also for the complexity of technical issues connected with the specifics of intellectual rights. Handling a case not only requires serious experience in legal practice but also requires skills in technical spheres. The judge considering such a case usually needs to understand some technical issues connected with intellectual property rights. The specialized IP Court provides efficiency of judicial proceedings by 
means of specialization of judicial practice in this area. Narrow specialization of judges increases the quality of judicial work, and reduces the consideration time of a case.

The Russian Intellectual Property Court was established in 2011. However, the idea of a specialized IP court was announced for the first time in the late 1980s. Prior to its creation, there were a number of drafts on this topic and even some laws supported this idea and contained the provisions concerning the necessity to establish a specialized IP court. The creation of the Patent Court of the USSR was stipulated in the 1988 Law "On Inventive Activity in the USSR" (Arts. 55, 56), in the 1991 USSR Law "On Inventions in the USSR" (Arts. 14, 15, 25, 42, 43), in the 1991 USSR Law "On Industrial Models" (Art. 26), in the 1991 USSR Law "On Trademarks and Service Marks" (Art. 32). The USSR Law "On the Patent Court of the USSR" did not come into force. The Concept of Judicial Reform in the Russian Federation (1991) designated a need for court specialization and judicial specialization. The 1992 Law "On Trademarks" provided for the creation of the Patent Court of the Russian Federation. However, the legislator refused this idea in favor of an administrative order on dispute settlement in this area. In 2010, the project of the Federal Constitutional Law "On Patent Courts of the Russian Federation" providing for the formation of an independent patent court system was brought to the State Duma, but was not accepted. The initiative for creating today's Intellectual Property Court was that of the Supreme Commercial Court of the Russian Federation, which even adopted a special Plenum Resolution in 2013 on this court's functioning.

The IP Court sits in Moscow. The structure of the Court consists of the presiding judge, two deputies, a presidium and two judicial panels. There is also an Academic and Advisory Council. The Court uses the Arbitrazh (Commercial) Procedural Code as the procedural rules for considering cases.

The IP Court acts as both a court of first instance and a court of cassation. Despite the fact that the IP Court is part of the commercial court system, the criteria of jurisdiction of commercial courts do not apply to it: its competence does not depend on the nature of the dispute (economic or personal) or on the status of the subject to a dispute (citizen, legal entity or sole trader).

As a court of first instance, the IP Court considers: cases of contest of legislative acts of the federal government in the sphere of intellectual property; and cases of disputes on intellectual property activity. As a court of cassation, it considers: cases previously considered in the IP Court as a court of first instance; and cases in the sphere of intellectual property decided by arbitrazh (commercial) courts.

\subsection{Juries}

Jury trial is one of the controversial questions of the Russian legal system. Jury trial was first introduced to Russia in the second half of the nineteenth century. It was a part of the Great Judicial Reform of 1864, together with the introduction of professional judges and attorneys, notaries public, and civil and criminal procedural reforms. 
Anglo-Saxon legislation served as the model for the Russian jury at that time. These early jury trials were only implemented in Saint Petersburg and Moscow. Only men could be appointed as jury members. The court with jury had the power to consider 410 offenses according to the Russian Criminal Code. That is around 20 percent of all offenses. In 1878, several offenses were excluded from the competence of the jury, e.g. murders of officials and breaches of the peace. A jury consisted of twelve persons; it was independent from the professional judge and did not participate in civil cases.

In 1917, jury trials were abolished by the Soviet government and lay assessors replaced juries. This model was borrowed from the German Schöffen model. Two lay assessors considered criminal and civil cases together with a single professional judge. They served for a term of two and a half years. In contrast to the jury member, the Soviet lay assessor had the power to consider, together with a judge, not only the determination of a fact, but also the meaning of a law.

In 1993, jury trial was reintroduced in Russia by the Constitution (Arts. 20, 32, $47,123)$. The current Russian jury system is a mix of the nineteenth century-model and Anglo-Saxon legislation. A jury's jurisdiction is limited to aggravated murder, racketeering, aggravated bribery and crimes against justice. Juries are not involved in civil cases and cannot consider crimes against the state.

At trial, a jury consists of twelve members. They are selected from a list of fifty candidates who must be at least twenty-five years of age and must not have criminal records. The judge pronounces the decision in the case on the basis of the jury's verdict. In December 2015, President Putin proposed reducing the number of jurors to between five and seven.

Here are some interesting jury-related statistics. Pilot juries were implemented in 1993-1994 in nine federal regions. Currently, jury trials operate in all regions. The last region to introduce trial by jury was Chechnya in 2010. In 1993, juries considered two cases, in 1994 they considered 173 cases. Currently they consider around 500 cases annually, which is approximately 1 percent of all criminal cases.

\subsection{Judicial Statistics}

In Russia in 2013 there were around 2,500 courts of general jurisdiction and 111 arbitrazh (commercial) courts; and around 30,000 judges, including 4,000 arbitrazh (commercial) judges and 7,400 justices of the peace.

Cases in arbitrazh court, whether in a court of first instance, appellate instance or cassational instance, last around nine months. In practice, the court may accelerate the proceedings and the claimant may not pass through all judicial stages, so cases often last around five or six months. Cases in a court of general jurisdiction last two or three months for a simple case, such as one for recovery of costs for damage caused by a car accident, and can last some years for complicated cases, such as one over inheritance or a real estate dispute, but generally last around six to eight months. 


\section{Stages}

There are several stages of the court proceedings.

\subsection{The Institution of a Civil Case}

The institution of a civil case in court can be carried out by submission of a claim, complaint or statement. The judge is obliged to decide on the initiation of proceedings in a case within five days from the moment of receipt of the claim. The judge issues a ruling by which the civil case is instituted in the court of the first instance. Generally, all the necessary steps for the acceptance of the claim and institution of a civil case have to be taken on the same day the plaintiff appealed to the court.

When accepting the claim the judge has to check whether the person concerned has the right to an appeal to the court for judicial protection and whether it is carried out according to a certain due process. The conditions for the initiation of the proceedings are:

1) following a pre-trial dispute resolution procedure by the plaintiff;

2) jurisdiction over the subject matter to a particular court;

3) procedural capacity of the plaintiff;

4) having the authorities for the administration of the case;

5) following the requirement of a written form of the claim;

6) payment of the state tax.

If any of these conditions is missing, the judge has either to return the claim, or to refuse its acceptance, or to leave the claim without progress.

\subsection{Preparation for the Trial}

The institution of a civil case is followed by the second stage - preparation for the trial. The purpose of this stage is to provide the prompt and correct adjudication of the case within one court session, to eliminate the judicial red tape and bureaucracy in legal proceedings. This stage consists of the following procedural actions.

The plaintiff transfers to the respondent a copy of the evidence, and files motions for the discovery of the evidence if it cannot be received without the aid of the court.

The respondent can clarify the claim and the actual grounds of the claim with the plaintiff, present the objections to the claim before the plaintiff and the court, transfer the evidence that proves the objections and file motions for the discovery of the evidence if it cannot be received without the aid of the court.

During the preparation stage the judge:

- guides the proceedings and explains to the parties their procedural rights and duties;

- examines the plaintiff or his attorney on the claim and offers to introduce the additional evidence, if necessary; 
- examines the respondent on the circumstances of the case, determines whether there are objections against the claim and what the basis is for the objections;

- resolves an issue of the co-plaintiffs, co-defendants and the third parties joining the proceedings, an issue of the replacement of an improper defendant, or an issue of joinder or separation of separate claims;

- takes measures to reconcile the parties, to reach the settlement agreements and explains to them the right to apply to the arbitration court for dispute settlement;

- informs the persons and the organizations concerned on the time and the place of the trial;

- resolves an issue of the summon of witnesses;

- commissions an expert assessment and the experts;

- resolves an issue of subpoena to appear as an expert or a translator;

- discovers the evidence which parties cannot receive independently on request of the parties and persons participating in the case and other persons participating in the case;

- makes view of the premises;

- takes provisional measures application;

- appoints the preliminary court session.

\subsection{Trials}

The third stage is the trial. In this stage consideration of the merits takes place and usually it ends with adjudication. Trials consist of four parts: (1) preparatory part; (2) consideration of the case on the merits; (3) judicial pleadings; and (4) adjudication and announcement of the decision. All of them, having a certain independence, are closely connected and consistently follow each other.

The task of the court in the preparatory part is to examine whether there are the necessary conditions for the trial in the particular court session. For this purpose the court has to resolve three issues: (1) whether consideration of the case is possible with the particular composition of the court; (2) whether hearing of the case is possible if any of the persons participating in the case are not present during the court session; and (3) whether consideration of the case is possible with the present evidence.

At a certain time the chairman opens the court session and announces which case is subject to consideration. Then the court session secretary reports who from the persons summoned before the court is present, whether absent participants were informed about the case hearing and what the reasons for their absence are. In practice, these procedural actions are quite often made by the chairman himself.

The witnesses present leave the courtroom prior to their interrogation. It is explained to them that they will be recalled into the courtroom for testifying. The chairman ensures measures so that the witnesses interrogated cannot communicate with others not interrogated. 
The chairman announces the composition of the court - the prosecutor for the case, the attorneys of the parties, the third parties, the expert, the specialist, the translator, the court session secretary - and explains their right to self-recusals and recusals. The judge, the prosecutor, the court session secretary, the expert, the specialist and the translator cannot participate in the trial and are subject to recusal if they have a personal, direct or indirect interest in the outcome of the case or if there are other circumstances raising doubts as to their impartiality. The judge cannot hear the case if (1) in the previous consideration of the same case he participated as a prosecutor, attorney, witness, expert, specialist, translator, court session secretary; (2) he is the relative of any participant in the case, or their attorney; or (3) he has a personal, direct or indirect interest in the outcome of the case or if there are other circumstances raising doubts as to the objectivity and impartiality of the judge.

The chairman asks whether the participants have any motions or statements. If there are any statements or motions on evidence discovery or on other issues connected with the case trial, the court is obliged to hear the opinion of other participants in the case. The statements and motions are resolved by issuing a court ruling, by which the motions are granted or dismissed. These rulings have to be reasoned. The judge is obliged to announce the issued ruling immediately.

The second part of the trial - consideration of the case on the merits - begins with the report of the chairman. In the report, the judge has to state briefly: (1) who the plaintiff is, who the respondent is and what the grounds for the claim are; (2) whether there are written objections of the respondent and what their essence is; and (3) all the evidence available in the case.

All administrative actions made by the parties in the courtroom have to be recorded accurately. The plaintiff's statement of renunciation of the suit, recognition of the claim by the respondent or the conditions of the settlement agreement of the parties have to be placed on record and signed, respectively, by the plaintiff, the respondent or both parties. If the administrative actions mentioned are expressed in the written statements addressed to the court, these statements have to be added to the case materials and placed on record.

For the sake of ascertaining to the fullest extent possible the facts and circumstances, the persons participating in the case are granted the right to ask each other questions. The questions are set with the permission of the chairman, who has to ensure that the questions concern the merits of the considered case. The judge rejects the questions which do not concern the merits of the considered case.

Having heard and having announced the explanations of the persons participating in the case, the court has to establish the sequence of further evidence discovery, an order of interrogation of witnesses, experts and the order of discovery of other evidence. The court resolves this issue, having listened to the opinions of the persons present and participating in the case. Most often, the court begins the evidence discovery with the interrogation of witnesses. Each witness is interrogated separately. 
The chairman, having revealed the relation of the witness to the persons participating in the case, invites the witness to report everything that he or she knows personally that relates to the case. The witness testifies in a free form about the circumstances he or she knows. After the testimony the witness can be asked questions. The party and the party's attorney who called for the witness ask first, and then the other persons participating in the case and their attorneys may ask their questions. The witness called at the initiative of the court is asked by the plaintiff first. Judges can ask the witness questions at any time. At the interrogation of witnesses under the age of fourteen and witnesses between the ages of fourteen and sixteen by court order their teacher will be called. In case of need parents, adoptive parents, trustees or curator are called. The mentioned persons can ask questions of the witness with the permission of the chairman.

For the sake of the protection of personal correspondence, written evidence can be revealed (announced) and investigated in a public hearing only with the consent of the person who is the author of the correspondence. Otherwise a private hearing will take place and the court will issue a special ruling.

The court examines the material evidence, and it is shown to the persons participating in the case.

Unlike the former Civil Procedure Code of 1964, the new Code allows examination of audio or video recordings during the court session.

After the examination of all the evidence the chairman gives the floor to the prosecutor. The prosecutor draws general conclusions on the merits of the case. The prosecutor has to:

- briefly state the public importance of the considered case;

- analyze in detail the examined evidence and specify which evidence can be considered reliable;

- state which facts were established in court and which should be considered unspecified.

To conclude, the prosecutor is obliged to refer to the legal norms that have to be applied in the consideration of the case, and to specify how in his opinion the case needs to be adjudicated based on the presented norms.

After the conclusions of the prosecutor, the judge asks the parties to the case or their attorneys whether they wish to present additional explanations. In the absence of such statements, the chairman announces the consideration of the case on the merits to be completed, and the case passes to the judicial pleadings.

The next part of the court proceedings - the judicial pleadings - aims at summing up the results of the examination of the evidence. The persons participating in the case state and give reasons for their conclusions about which evidence should be considered reliable, which facts of the case should be considered established and which unspecified, what the content of the dispute is, which law should be applied and how the case should be adjudicated. 
The judicial pleadings consist of the statements of the parties to the case and their attorneys. In the judicial pleadings the plaintiff and his attorney come first, then come the respondent and his attorney. Following the statements of all participants in the judicial pleadings, they can make remarks regarding their statements. The right of giving the final remarks always belongs to the respondent and his attorney. The participants in the judicial pleadings have no right to refer to circumstances that were not investigated in the court session, nor to refer to the evidence that was investigated. After the judicial pleadings the chairman announces that the court will retire to chambers to consider its decision.

The next part of the trial is the delivery and announcement of the decision. During the discussion and the delivery of a decision only the judges who are part of the composition of the court for the case are allowed in chambers. The presence of other persons in chambers is not allowed. Such order creates the conditions for excluding additional pressure on the judges during adjudication. Violation of the secrecy of meetings of judges is the unconditional grounds for the reversal of judgment. All the issues arising during the trial are resolved by the means of majority voting. When considering each issue, none of the judges has the right to abstain from voting. A judge not in agreement with the solution of the majority can state a dissenting opinion, which is added to the case material.

In chambers, the judges have to analyze and evaluate the seized evidence based on comprehensive, complete and objective examination of all the facts of the case presented in the court session, being guided only by the law and their sense of justice.

The court adjudicates the case based on the requirements declared by the plaintiff. However, in some cases provided by law, the court can go beyond the declared requirements. The court is obliged to deliver the decision immediately after the trial. When dealing with a particularly difficult case the delivery of the reasoned decision can be postponed up to five days, but in this situation the operative part of the decision has to be announced in the same court session that the case trial ended. After signing the decision the judges return to the courtroom where the chairman announces the decision.

The structure and contents of the decision are regulated by the Civil Procedural Code. This consists of four parts stated in strict sequence: the introductory part, the descriptive part, the rationale for the judgment and the operative part.

The introductory part has to contain the time period taken for adjudication, the place of adjudication, which is defined by the location of the court hearing for the case, and the name of the court that delivered the decision as well as the court's composition.

The descriptive part of the decision has to contain the requirements stated in the claim, and the circumstances confirming the requirements. It reflects the respondent's position. If there are objections from the respondent, the reasons for the claim's non-recognition are stated briefly. 
The rationale for the judgment has to contain the actual and legal justifications for the court's conclusions. It also contains the facts of the case established by the court, the evidence on which the conclusions are based, the argumentation for the court's rejection of the evidence if so determined and the laws on which the decision is based.

In the operative part of the decision the results of the judicial proceedings are presented in a concise and final manner: a conclusion about the satisfaction of the claim or the dismissal of the claim in full or in part. The operative part clarifies what the court has decided on each issue separately and on the counterclaim, which of the parties enjoys the challenged right, and what actions need to be taken by the liable person.

Generally, the trial of a civil case ends with the decision. But in some cases it ends without it. There are two forms of the termination of proceedings without a decision: discontinuance of proceedings and leaving the claim without consideration.

These forms differ both in terms of the grounds and in terms of the legal consequences of them. The discontinuance of proceedings generally takes place when the plaintiff does not have the right to judicial protection. Therefore, the discontinuance of proceedings excludes the possibility of instituting a second proceedings for the same case. Leaving the claim without consideration may occur when the plaintiff or the applicant has the right to judicial protection but the conditions of its realization were not met. In the case of leaving the claim without consideration the plaintiff or the applicant does not lose the right to initiate identical proceedings in court again after the elimination of the defects.

\subsection{Review Proceedings}

A court decision may contain errors or simply be unjust or even illegal. The right to appeal and review judgments is one of the basic rights that is recognized by most procedural systems. Appellate review is the opportunity for the parties to try to correct an injustice that may be contained in a judgment. Two different systems of review are widespread in the world. Which one is used depends on the kind of judicial errors that are considered by a court of the review instance: errors of fact or errors of law.

The Russian system of review is influenced by continental European legislation, especially by French and German law. Such legislation provides for appellate and cassational procedures. However, uniquely, the Russian system also provides for supervisory proceedings. Russian review proceedings are divided into four categories:

1) appeal;

2) cassation;

3) supervisory proceedings;

4) an appeal founded on new or newly discovered facts.

The decisions of a court of the first instance that have not yet entered into force may be appealed through the appeals procedure. The appellate court rehears the 
case with full authority to review all the circumstances in the case. The court will assess all evidence presented in the first instance, as well as any new evidence. Cases in a court of an appellate instance are examined by panels of judges, not by a single judge. An appeal has to be filed within one month of the date on which a court of the first instance issued the decision in its final form.

A court of cassation is not entitled to consider matters if they were not established by a court of the first instance. It does not review the circumstances of the case and does not admit new evidence, rather the court will only consider the correct application of material and procedural law and the legal reasoning behind the application. Nor can it rule on the credibility of evidence. Parties to the case cannot ask the court to consider new evidence; they can only present the evidence that was examined by the court of the first instance. It is required to base the factual deliberations on the facts as established by a court of the first instance. A court of cassation can also remit a case for retrial.

After the cassation process, a supervisory appeal may potentially be filed. A supervisory procedure is an exceptional feature of Russian civil procedure. Review by way of supervision is a special procedure that allows additional re-examination of judgments which have already entered into legal force. It stems from legislation of the Russian Empire of the seventeenth, eighteenth and nineteenth centuries.

During the Soviet period, the right to apply to a supervisory court belonged only to a limited number of officials, such as chief judges and their deputies and the Procurator General and his deputies. Parties to a case did not have such right. In 19808,618 decisions were revoked by way of supervision. In contrast, 12,500 were revoked by way of supervision in 1989 .

In modern Russia, review by way of supervision is regulated in a different manner. It is stipulated in the Constitution and in the new 2003 Civil Procedural Code. It exists in addition to the appeal and cassation instances and allows for the re-examination of judgments which have already entered into legal force and which may have already been decided under a cassational appeal. The right to apply to the court of supervision belongs only to the parties to the case and any other persons whose rights were abused by the judgment. Appeals via supervision may only be considered by the Presidium of the Supreme Court, by military assembly of the Supreme Court, by judicial tribunal of the Supreme Court for civil cases, by presidium of a military court, and by Presidium of the Supreme Court of a "subject" (state) within the Federation. It is possible to appeal to a court of supervision within three months of the date on which a judgment enters into legal force.

When reviewing a case by way of supervision, the court considers only questions of law on the basis of materials available in the case. Although the supervisory instance may refuse to accept lower courts' findings of fact, it has no power to establish new facts or to consider new evidence. As a general rule, the court verifies the correctness of the application and interpretation of provisions of material law and norms of procedural 
law by the courts of the first and cassational instances only within the limits of the arguments contained in the appeal. However, in the interest of legality, the higher court may also go beyond the limits of the appeal. The court of the supervisory instance may render a new judgment when it is not necessary to consider additional facts or evidence. Some 300,000 appeals a year are considered by the courts of general jurisdiction by way of supervision. In 1996 15,215 decisions were cancelled in the supervisory instance and 20,270 in 2002. That is one-third of all annulled decisions. In contrast 17,482 decisions were annulled in the supervisory instance in 2004 (after the adoption of the new Civil Procedural Code). That is 20 percent of all annulled decisions.

The possibility of re-examining a judgment which has already entered into legal force is a moot point. Does this conflict with the principle of res judicata? There are two points of view. Some scholars believe that the supervisory instance is an additional opportunity to correct the decision and rectify judicial errors. Others emphasize that it conflicts with the principle of res judicata. The position of the European Court of Human Rights is interesting in this context. In Ryabykh v. Russia, No. 52854/99 dated 24 July 2003, it simultaneously maintains two different positions on the Russian supervisory instance. On the one hand, it believes that review by way of supervision conflicts with the principle of res judicata (Arts. 52, 55-57 of Ryabykh v. Russia, Art. 25 of Pravednaya v. Russia). On the other hand, it does not conflict with it because it is used to rectify judicial errors (Arts. 25, 28 Pravednaya v. Russia, Art. 52 of Ryabykh v. Russia).

Meanwhile, Russian supervisory procedure was reformed in 2010 and the right to appeal was limited to a strict number of cases. Nowadays, the supervisory appeal is the exception to the rule.

An appeal due to newly discovered facts is one of the ways of legal examination of the consideration of the case. Newly discovered facts are the facts that existed at the time of the consideration of the case and that are of significance for the correct adjudication of which the applicant or the court had no, and could not have had any, knowledge. The main objective of the court is to determine the existence or absence of newly discovered facts and to establish whether they affected the decision issued.

The decisions that have entered into legal force, court rulings of the first instance court and of the justice of the peace can only be the object of revision on newly discovered facts. The revision is carried out by the court that delivered the decision.

The grounds for the revision of decisions due to newly discovered facts are the following:

1) circumstances significant for the case, of which the applicant had no and could not have had any knowledge;

2) falsification of evidence, deliberately false expert opinion, deliberately false witness testimony, deliberately incorrect translation that resulted in the delivery of an unlawful or an unsubstantiated decision on a given case and established by an effective court sentence; 
3) criminal deeds of a person participating in the case or of his attorney, or criminal deeds of a judge, committed during the consideration of the given case and established by an effective court sentence.

Having considered the application, the court either satisfies it and reverses the decision, or refuses the revision. In case of reversal, the case is considered on the merits in the general proceedings.

\section{Administrative Procedure}

In 2015, a new Code of Administrative Procedure was adopted in Russia. Such a code has never existed before in Russian legal history. Historically in Russia, in contrast to some other countries, as soon as cases stemming from administrative relations became an allowed subject for judicial inquiry, their hearing was included in civil procedure, and certain sections were added to the Code of civil procedure. ${ }^{13}$

In 1993, the Constitution of the Russian Federation established separate legal proceedings for civil, administrative and criminal cases. Administrative procedure did not exist in practice until 2015 though related amendments were already being proposed in the mid 1990s. The Code of Administrative Procedure was approved by the Russian President on 9 March 2015 and entered into force on 15 September 2015.

With the adoption of the new Code, a number of laws and regulations concerning legal proceedings for the investigation of administrative cases have changed. The provisions regulating proceedings arising out of administrative cases have been excluded from the Civil Procedural Code, along with provisions on consideration of applications for compensation due to violations of the right to legal proceedings within a reasonable time, and on compulsory hospitalization of citizens in psychiatric hospitals.

Unlike the codes of civil and commercial procedures, the Code of Administrative Procedure emphasizes the active role of the courts. This is motivated by the unequal positions of the parties in relevant cases. In particular, if necessary, the court can call for evidence itself; and it can go beyond the bases and arguments of the declared requirements when checking the legality of legal statutory acts, decisions, actions and omissions.

Another innovation of the Code is the demand for confirmation that the participants in a trial have a higher legal education. The parties to administrative proceedings will also have additional expenses. However, all expenses, including attorneys' fees, any state duty and other expenses connected with the proceedings will be borne by the defeated party. Therefore, it is quite possible that it will be more expedient for many potential plaintiffs to pay penalties rather than risk incurring

13 Dmitry Tumanov, Public Interest and Administrative Legal Proceedings, 3(3) BRICS Law Journal 64 (2016). 
additional expenses and spending time on an administrative trial. On the other hand, officials will sometimes have to think twice before making a decision, as those additional expenses can also be collected from the state, which could be very unpleasant for the government.

Finally, the new Code provides additional guarantees for access to justice, and it makes the procedure more professional and specialized.

\section{Class Actions}

Among different types of group actions only public and organizational group actions are possible in Russia.

Since Soviet times, public group litigation has existed in Russia. The 2003 Civil Procedural Code provides for special regulation. According to its Art. 45 the attorney general can go to court to defend the interests of an indefinite group of persons. Organizational group actions are regulated in the same manner by Art. 46. These rules are expanded by special regulation in specific fields of law. For example, the Consumer Protection Law of 1992 (Art. 46) and the Securities Law of 1999 (Art. 19) contain similar rules to protect consumers rights. The problem is that the laws simply stipulate the right for the attorney general or organizations to sue. Specific (procedural) rules are not provided.

At the same time, there is a vibrant academic discussion regarding the introduction of private group actions. This discussion started along with the beginning of judicial reform in the 1990s. The relevance of improvement of groups rights protection mechanisms and mechanisms of protection of an unspecified number of persons are not called into question by the majority of procedure scholars. However, many researchers warn against the introduction of the Anglo-Saxon model of private class actions in Russia.

There have been several steps in the attempt to introduce private group actions in Russia. First, one option was offered while developing the Civil Procedural Code of 2003 , but it was rejected by the working group

Second, in July 2009 Federal Law No. 205-FZ"On Amendments to Certain Acts of the Russian Federation" was adopted according to which the special order of case hearing on group rights and legitimate interests protection was established in the Arbitrazh (Commercial) Procedural Code. This law introduced quasi-private group actions. Special provisions (Chapter 28.2 "Consideration of the Cases of Protection of Rights and Legal Interests of a Group of Persons") regulate the proceedings in such cases.

The claim has to concern not only personal, but also collective rights of other participants and, additionally, it has to be supported by at least five persons. Only at observance of these two conditions will the case be heard according to these special rules of the Arbitrazh (Commercial) Procedural Code. 
The person who appealed to the commercial court is the key participant in the class action proceedings. This person has the rights and performs the procedural duties of the claimant and is obliged to conscientiously protect the rights and legitimate interests of all members of the group. He can act without power of attorney, under documents on other persons' accession to the claim, which can be the written statement of one person, or the decision of several persons to accession. His powers can be stopped due to his renunciation of suit, or on request of most of the members of the group. In case of discontinuance the court postpones the judicial proceedings for its replacement. He has to notify other members of group if the need arises of carrying out replacement independently. If no member of the group agrees to act as this person, the court stops the proceedings on the class action.

Special rules of preparation for the court proceedings work for such cases as category hearings. The main specifics concern the procedure in respect of other persons joining in the statement of claim. In this stage the court has to define an order of formation of a group, joined to the claim. For this purpose it establishes the term during which it is necessary to make the proposal to other persons to join the class action, and also the term during which these persons can join it.

The duty to make such proposal, and also to inform the court on the joined persons and to provide the relevant documents falls on the person who initially appealed to the court. Such offer is to be made publicly. The court determines the concrete way of placement of the offer but, by the general rule, it is published in the mass media, or goes by mail with recorded delivery. The expediency of such order raises doubts. First, the duty of notice is assigned not to the court, as is established for notice of participants in the case, but to the initiator of the claim. Second, the list of ways of notice is open, which allows to reduce them to a formality and by that to limit membership of the group.

The existing rules insufficiently clearly define the status of the persons joined to the claim. If the initiator of the claim has the rights of the claimant and performs the claimant's duties as it is directly specified in Art. $225^{12}$ of the Arbitrazh (Commercial) Procedural Code, the legal status of the joined persons is not defined.

The class action has to be considered within five months from the date of rendering of the ruling on the initiation of proceedings of a claim. The established procedure of filing and hearing of the class action raises a number of remarks. The general condition of filing of the claim gives the chance for various interpretations: members of the group, except for the initiator of the claim, have almost no procedural rights; it is unclear whether members of the group have the right to appeal the decision; etc.

Unlike the classic Anglo-Saxon model of private class actions where the participants in the group do not always have to be clearly defined during the hearing, the Russian Arbitrazh (Commercial) Procedural Code establishes a necessary condition - formation of a group prior to judicial proceedings, at a preparation stage. Such regulation changes the nature of the classic construction of the class action. 
Therefore, on the one hand, the established procedure gives a chance to create a group, but, on the other hand - participants of this group have to be listed prior to the case hearing. Differences between this order and the institute of joinder of parties are minimum. The established rules of formation of a group do not contradict the norms of joinder of parties. Therefore, this procedure, in fact, is not an innovation of the Arbitrazh (Commercial) Procedural Code, it only concretizes the regulation of joinder of parties.

The third attempt to introduce private group actions in Russia is the initiative of the Federal Anti-competition Agency. Its group action amendments to the procedural codes and anti-competition legislation were drafted in 2012-2014. ${ }^{14}$ According to its 2012 Road Map "Developing Competition and Improving Anti-competition Policy," group actions should be introduced before the courts of general jurisdiction as well as the commercial courts. Finally, the amendments were formulated in the draft of the federal law"On Amendments to Certain Acts of the Russian Federation Regarding Settlement of an Order of Case Hearing on Group Rights and Legitimate Interests Protection (Group Proceedings)," but this law was never adopted.

The fourth attempt, in 2015, was the adoption of a new Code of Administrative Procedure. Such a code has never existed before in Russia. The Code entered into force on 15 September 2015. As already mentioned, due to the adoption of the new Code, a number of laws and regulations concerning legal proceedings for the investigation of administrative cases have changed. One such novelty is the new regulation on group litigation under Article 42 "Collective Administrative Claim." According to this article, the court should initiate group proceedings if at least twenty persons have joined the claim. They must select a person who will participate in the proceedings on behalf of the group. If somebody has filed a similar claim with similar subject matter and grounds, the court proposes to join the collective claim. This procedure cannot truly be defined as group litigation, because it requires an exact number of parties. Rather, it should be considered more a joinder of parties.

Therefore, today Russian legislation consists of only organizational and public class actions. There were a few attempts to introduce private class actions, but they failed.

\section{Enforcement of Judgments}

Winning a court case is usually not enough to obtain money or other relief from a debtor. It is only the beginning of a lengthy and challenging process of enforcement of court judgments and collecting debts. Therefore, the final part of a civil action is execution of the judgment. Without execution the goal of procedure is not achieved. The execution is regulated not only by the procedural codes, but also by special laws "On Execution" (1997) and "On Bailiffs" (1997).

14 Dmitry Magonya, Class Actions in Russia, 1(1) Russian Law Journal 63 (2013). 
The execution of the judgment is carried out by the court and bailiff service. In Russia, the big reform was initiated in 1997 when the Federal Bailiff Service was established. It became a part of the system of agencies of the Ministry of Justice. The Director of the Federal Bailiff Service is appointed by the President of the Russian Federation. The Federal Bailiff Service has been a member of the International Union of Judicial Officers since 2015. In order to become a bailiff a person must be a citizen of Russia and be at least twenty-one years old. There are no requirements concerning a university degree in law. Before presenting an applicant for the bailiff's position, there is a preliminary coordination of the candidacy with a medical commission.

There are four stages of the execution of the judgment: initiation of the execution, preparation for the implementation of measures of compulsory execution, implementation of measures of compulsory execution, and termination. The law provides for a general two-month deadline for the entire enforcement procedure. However, there are no sanctions for violation of this deadline, thus enforcement, in practice, could last much longer.

The initiation stage consists of the issuance of a writ of execution, its filing with the bailiff service and delivery of the court ruling on the initiation of the execution. The enforcement is mainly initiated on the basis of an enforcement order, which is issued by a court as soon as the decision comes into force. A writ of execution is the basic document which confirms the judgment creditor's right to enforce the court judgment. A writ of execution can be presented within three years from the entry of a judgment into legal force; however, the court has the power to grant an additional three months for presentation of the writ of execution. Writs of execution that contain requirements for periodic payments can be presented within the entire term for which payments are awarded, as well as within three years after the end of this term. A writ of execution is presented for enforcement at the place of execution of the judgment, which is usually the debtor's place of residence or the place where the debtor's property is located.

The preparation stage includes performance of the actions aiming at voluntary execution and establishment of the debtor and his property location. A five-day term for voluntary execution is established by a bailiff. After expiration of this period, enforcement is started. The debtor bears an enforcement fee (7\% of the amount claimed) in a case of refusal of voluntary execution without reasonable cause. There also could be expenses for enforcement actions and bailiff's fines. The bailiff also send inquiries to different state and non-state authorities and agencies such as the tax service, the police and registration offices for searching the debtor's assets.

Implementation of the measures of compulsory execution consists of garnishment (seizure), property disposal and distribution of the collected money. The garnishment (seizure) includes performance of two obligatory actions such as taking inventory of assets and imposing an injunction on the rights of disposal thereof, and, if required, three optional actions such as restricting the right to use the property, the inventory 
of the property and a ban on disposal of the property. The amount obtained by the bailiff from the debtor is transferred for satisfying the creditors' claims in the following priority: first, claims regarding alimony and compensation for accidental and deathcausing injuries; second, employees' claims arising out of contractual relations; third, claims regarding payments to state non-budget funds; and fourth, all other claims.

The termination can either be a return of the writ of execution without execution, or the termination of execution. The latter requires an additional court ruling.

There are a number of particular measures in Russian enforcement procedure. First, one of the most popular indirect enforcement measures of recent times is the prohibition to leave the country. This measure has been effective since 2007. The bailiff can prohibit the debtor from traveling abroad if the debt is more than 10,000 RUR. This measure was performed in relation to 2 million debtors in 2016, 50 percent of them were claims regarding alimony.

It is necessary to note that unlike many countries criminal arrest of debtors in relation to civil cases is not used in Russia. This appeared in Russian case law in 2013.

Among indirect enforcement measures there is also astreinte in Russian legislation. ${ }^{15}$

A special enforcement procedure is established in relation to official state authorities if they act as debtors. This concerns the government, ministries, official agencies, etc. The general rules are excluded in this case, and special legal regulation has been established. The Budget Code (1998) provides the rules concerning the enforcement of such judgments. The Federal Bailiff Service does not have authority to enforce them. A writ of execution should be delivered to the Treasury Department, which acts as the enforcement organ.

Finally, some statistics (2015). There are 25,000 bailiffs in Russia. On average, about 2,200 cases are pending with each bailiff every year. Thirty million cases are initiated every year by the bailiffs. There were around 324,000 garnishments (seizures) of property performed by the bailiffs.

\section{Arbitration}

First of all, it should be kept in mind that justice in the Russian Federation is conducted solely by courts, which means that no other authority other than the court has the power to render an obligatory decision to parties at trial.

Russia is a party to the New York Convention on the Recognition and Enforcement of Foreign Arbitral Awards. The USSR was one of the original member states to sign the convention in 1958. There is a distinction between international and domestic arbitration. Arbitration in Russia is regulated by Federal Law "On Arbitral Tribunals in the Russian Federation" (2003) (domestic arbitration), and also by Federal Law

15 Francesca Ferrari \& Natalya Bocharova, The astreinte in the Italian and Russian Administrative (Judicial) and Civil Proceedings, 3(3) Russian Law Journal 24 (2015). 
"On International Commercial Arbitration" (1993) (international arbitration); this law was drafted on the basis of the UNCITRAL Model Law on International Commercial Arbitration.

The general rule of arbitrability states that any dispute is arbitrable unless otherwise directly stated by law. The arbitrators cannot be state court judges; if the panel consists of three members, then at least one of them should be a lawyer. It is possible to appoint foreign nationals as arbitrators in international arbitral proceedings. A court cannot intervene in the selection of arbitrators. An arbitral tribunal can decide on its own jurisdiction. The parties have the right to agree on the procedure to be followed by the arbitral tribunal in conducting proceedings. Parties are free to agree on a language other than Russian being used in the proceedings. An arbitration award cannot be appealed. A party can make an application to the competent court for enforcement of the award and that application should be heard within three months.

The following disputes cannot be resolved by arbitration, but only by state commercial courts: corporate disputes (before 2016); intellectual property disputes; bankruptcy; public law disputes, among others. There is also a risk of non-arbitrability of other types of disputes due to the lack of legal regulation and different courts' interpretations. For example, Russian courts recently confirmed that disputes arising from government-related contracts are not arbitrable.

Most arbitration in Russia is institutional. Ad hoc procedures are not popular. There are around 500 arbitral institutions in Russia and only seven to ten of them could be considered important, with their own set of rules and the option of cross-border disputes resolution. The leading such institution is the International Commercial Arbitration Court at the Chamber of Commerce and Industry of the Russian Federation in Moscow (ICAC). Its history dates back to 1932 when the USSR founded the Foreign Trade Arbitration Commission. It is the most frequently used court for international arbitration in Russia and handles an average of 200 to 250 cases per year. In 2013, the National Russian Arbitration Association was created as an independent arbitration institution and an alternative to ICAC.

The previous system of arbitration had several disadvantages. One of them was the dramatic increase in the number of arbitral institutions over the last fifteen years. Many arbitral institutions were established by major corporations and are influenced by them; this is known as a "pocket" arbitration.

The most recent reform of arbitration in Russia started in 2014. The first draft law on arbitration was introduced by the Russian Ministry of Justice in January 2014, but it was returned by the government for revision. In May 2015, the government introduced a revised draft law in parliament. Finally, the President signed Federal Law "On Arbitration in the Russian Federation" and Federal Law "On Changes to Related Laws of the Russian Federation." The first law regulates domestic arbitration, while the second concerns international arbitration. 
There are three important aspects to the recent reform: first, the arbitrability of corporate disputes; second, the more detailed regulation of the arbitral proceedings; and third, the licensing of the arbitral institutions.

Corporate disputes were non-arbitrable before the reform. This rule was stipulated not by the legislation but by court practice. The new laws determine the arbitrability of this category of disputes. However, there are some limitations. For example, the seat of arbitration of corporate disputes must be only in Russia.

The new laws establish a number of administrative requirements for arbitral institutions. They introduce very strict rules of arbitration. The new laws are similar to procedural codes. State courts have more influence over arbitration, which could eventually lose its effectiveness as an alternative form of state litigation. Many details are now stipulated in the legislation. For example, the duty of an arbitral institution to publish information about its cases on the internet.

Most of the institutions must obtain the licenses provided by the government. All foreign arbitral institutions should also obtain certification from the government. The new Council of Arbitral Development is established under the supervision of the Ministry of Justice. It gives preliminary approval in the licensing proceedings. In general, the new laws make ad hoc arbitration less preferable than institutional arbitration due to the increasing control by the state courts over them as well as a number of restrictive rules, for example, by excluding ad hoc arbitration in corporate dispute resolution.

There are other novelties in the laws. They allow retired judges to act as arbitrators. There is also a very important regulation that clarifies that a foreign arbitral award, which does not require enforcement, is recognized in Russia automatically without any recognition proceedings.

It could be concluded that the general trend of the reform is the increasing state control over arbitration. However, the new regulation is very important; it makes huge changes and could be qualified as the start of a new era in arbitration in Russia.

\section{Conclusion}

The global era of today is the time of the increased role of civil justice. Different procedural systems are spread across the modern world. The most common are the Continental, Anglo-Saxon and mixed systems. The frontier between the two classic models of civil procedure has blurred, and it appears that a unified procedural system is emerging. At the same time, some distinctive and unique procedural systems still exist. The Russian system of civil procedure is one of them.

\section{References}

Berman H.J. Justice in the USSR: An Interpretation of Soviet Law (New York:Vintage Books, 1963). 
Butler W. Russian Law ( ${ }^{\text {rd }}$ ed., Oxford: Oxford University Press, 2009).

Cappelletti M. Social and Political Aspects of Civil Procedure: Reforms and Trends in Western and Eastern Europe, 69 Michigan Law Review (1971).

Chenworth D.W. Soviet Civil Procedure: History and Analysis, 67 Transactions of the American Philosophical Society (1977).

Conlon B. Dostoevsky v. the Judicial Reforms of 1864: How and Why One of NineteenthCentury Russia's Greatest Writers Criticized the Nation's Most Successful Reform, 2(4) Russian Law Journal (2014).

Ferrari F. \& Bocharova N. The astreinte in the Italian and Russian Administrative (Judicial) and Civil Proceedings, 3(3) Russian Law Journal (2015).

Maleshin D. The Russian Style of Civil Procedure, 21 Emory International Law Review (2007).

Osakwe C. The Public Interest and the Role of the Procurator in Soviet Civil Litigation: A Critical Analysis, 18 Texas International Law Journal (1983).

Quigley J. Socialist Law and the Civil Law Tradition, 37(4) American Journal of Comparative Law (1989).

Reshetnikova I. Judicial Reforms in Russia: 1864 to 2014, 3(2) Russian Law Journal (2015).

Solomon P. Judicial Power in Russia: Through the Prism of Administrative Justice, 38(3) Law \& Society Review (2004).

Tumanov D. Public Interest and Administrative Legal Proceedings, 3(3) BRICS Law Journal (2016).

Van der Pol R. \& Petrov A. Searching for Truth in Civil Process: The Netherlands and Russia, 3(1) Russian Law Journal (2015).

Vyshinsky A. The Law of the Soviet State (New York: Macmillan, 1948).

\section{Information about the author}

Dmitry Maleshin (Moscow, Russia) - Professor of Civil Procedural Law, National Research University Higher School of Economics (3 Bol'shoy Trekhsvyatitel'skiy pereulok, Moscow, 109028, Russian Federation; e-mail: dmitry.maleshin@gmail. com). 